\title{
Transcription Factor AP-2-Beta
}

National Cancer Institute

\section{Source}

National Cancer Institute. Transcription Factor AP-2-Beta. NCI Thesaurus. Code C17970.

Transcription factor AP-2-beta ( $460 \mathrm{aa}, \sim 50 \mathrm{kDa}$ ) is encoded by the human TFAP2B gene. This protein plays a role in transcriptional regulation, face and limb development, and differentiation and function of renal tubules. 